\title{
Redirecting Tragedy towards the Unique Approach of Ama Ata Aidoo's Anowa
}

\author{
Samuel Yirenkyi ${ }^{1 *}$, Stephen Yaw Oppong ${ }^{2}$ \\ ${ }^{I}$ Department of Theatre Arts, University of Education, Winneba, Ghana \\ ${ }^{2}$ School of Creative Arts, University of Education, Winneba
}

*Corresponding Author: Samuel Yirenkyi, Department of Theatre Arts, University of Education, Winneba, Ghana Winneba, Ghana

\begin{abstract}
Except for the peculiar cultural concepts of tragedy as a dramatic genre, the Aristotelian tragedy and the contemporary tragedy of the common man by Arthur Miller have seemingly been internationally considered as the main concepts that define tragedy and the tragic hero/heroine. Could there not be a better way to see tragedy that will be at the peak by its manifestation of the characteristics of both the Aristotelian tragedy and tragedy of the common man? This paper focuses on redirecting the concept of tragedy in the attempt to finding a topnotch tragedy that will unite the hitherto contrasting Aristotelian Tragedy and Arthur Miller's Tragedy of the Common Man through the unique approach of Ama Ata Aidoo in her play: Anowa. This is done through textual and structural analysis. It is recommended that contemporary playwrights will adopt this recommended approach to define the concept of tragedy in the attempt to presenting the flaws in life to readers of tragedy
\end{abstract}

Keywords: concepts, tragedy, redirecting, Aristotelian, Play, cultural

\section{INTRODUCTION}

The world from time immemorial has seen and appreciated many art forms, some of which are extant today. Two of such art forms are drama and theatre. Grainger (2014) argues that drama and theatre are mostly used interchangeably. According to Prince and Jackson (1997, p. 7 ), drama, which evolved from a Greek root meaning "to act" or "to do" is primarily a written story that is supposed to be acted out on a stage. By extension, drama covers any story, whether written or improvised which is intended to be enacted on a stage to a live audience.

On the other hand, theatre, from the Greek word "Theatron" which means "seeing place" is the performance of drama on a stage by actors to engage audience (Worthen, 2004, p1). Worthen explains further that theatre is an event in that it happens within a specific time and space (on the stage.) Theatre then can be seen as an activity by which drama is translated or rendered into action. Theatre therefore gives life to drama so that the cold or abstract characters in literature; whether oral or written begins to experience the life of human action: breathe, walk, talk, eat, drink, feel as has been determined for them by the playwright to communicate the ideas of the playwright to live audience in a theatre; the auditorium which is the seeing place as the Greek root of the term suggests. This makes theatre an imitation of life through performance.

Drama has many genres (forms) each of which has peculiar characteristics that describe it. Hamilton (2012) outlines the four leading forms or genres of drama as tragedy, melodrama, comedy and farce. However, tragedy is the oldest of all genres of drama. Tragedy has often been employed in various dictionaries to describe a catastrophe or any mishap in the society; however, there is more to tragedy than this.

Although tragedy can by far be extended to prose, Sewall (2016) defines the term in a broad spectrum as a field in drama that tells the serious and sorrowful encounters of the life of a hero, which leads to the fall of the hero and enlightens the audience of the role of man in the universe. This is true about tragedy. Its approach is a serious one in that it affects the soul of the audiences and keeps the 
audiences in balance since it casts images of the horror and terror seen from the stage on the minds of the audience.

Sifakis (2003) explains that tragedy took rise in the 5th Century BCE from the Greek term "tragoidio" which means "he-goat singers" and has secured two main scholarly considerations regarding its origin. Whereas one of the schools of thought defends that the branch of drama was named tragedy because the prize to the best performance of pre-dramatic choruses of the ancient Greeks was a goat, another school of thought holds that the performers of the pre-dramatic choruses dressed and made-up in cloths and masks of goat skins to disguise themselves during the performance of the choruses.

Cartwright (2013) provides additional information to Sifakis' second point of the scholarly debate over how the term tragedy evolved. Cartwright agrees with Sifakis on the point that some scholars believe tragedy (tragoida) originated from the performance of the epic poetry (pre-dramatic choruses) that was performed. He adds that, the second school of thought believes that as part of the worship of Dionysus, a goat was sacrificed; worshippers wore masks, drank wine, and lost control of themselves under the influence of the wine and begun to step out of their natural way of life as actors do. This is what might have resulted in the reference to Dionysus as the god of theatre and is more probable to be the root from which tragedy evolved. Whichever is the case, one thing is clear. Tragedy is associated with the worship of Dionysus and the pre-dramatic chorus called dithyrambic.

\subsection{Theorizing Drama: Focus on Tragedy}

Although tragedy as a drama and theatre genre had been practiced for over a century in ancient Greece, there had been no formal documentation that sought to discuss how tragedy worked in drama and theatre. Aristotle's Poetics which according to Stennud (2006) dates back to the 4th Century BCE has been recognized by all generations who have known the extant document that gave drama and theatre its structure.

Stennud (2006) reveals that although the Poetics has lived for more than 24 Centuries now, it has still remained the document that treats drama and theatre in the best way ever. Although, there have been various concepts others have written regarding the theory of drama, to Stennud they are all commentaries that build on how best people can understand the Poetics by Aristotle. Aristotle's Poetics has therefore been a major reference material for drama to all generations who have known the text of the document.

A critical consideration of Butcher (1902), an English translation of Aristotle's Poetics reveals that Tragedy is at the core of the Poetics because it seems to be what Aristotle himself took so much delight in.

\subsection{The Aristotelian Tragedy}

The Aristotelian tragedy can be summarized into the following groups as based on the translated version of Poetics; Butcher (1902) or otherwise specified. In the first place Butcher (1902) presents Aristotle's definition of tragedy.

Tragedy, then, is an imitation of an action that is serious, complete, and of a certain magnitude; in language embellished with each kind of artistic ornament, the several kinds being found in separate parts of the play in the form of action, not of narrative; through pity and fear effecting the proper purgation of these emotions. (p.23)

In the first place, Aristotle identifies and explains six (6) main elements of tragedy. These are plot, character, thought, diction, music and spectacle. Aristotle further provides some cautions to guide the playwright whose desire is to create a perfect tragedy. These cautions are such that they provide what the playwright must do and must not do in constructing the plot.

According to Aristotle, perfect tragedy must have a complex plot and imitate actions which evoke pity and fear. This means that the more complex the plot is, the better pity and fear are evoked leading to the right purgation of emotions. Actions that are aimed at evoking pity and fear must be between close or dear characters in the tragedy. For instance, it must be between a son and his beloved father or mother, a brother and his beloved sister, a husband and his beloved wife and the like. This is because, 
if one kills his enemy, it has no power to arouse neither pity nor fear; for there is no good wish for an enemy, but for a son to kill his father as did Oedipus in Oedipus Rex or vice versa, it is traumatic and emotion striking.

Furthermore, Aristotle provides the characteristics of the tragic hero. Citing Oedipus and Orestes as models for a tragic hero, he provided the following as what could qualify one to be a fitting tragic hero or heroine in the case of a female like Medea in Euripides' Medea.

The tragic hero or a heroine, that is, the character who suffers the tragedy must neither be wholly vitreous person nor a villain but his/her misfortune/flaw must not be a result of vice or immorality. It must rather be the result of an error perpetrated in ignorance or weakness he/she is unable to overcome. This makes his situation a pathetic one, leading to the audience's fear of encountering a similar situation in life. This brings about catharsis; purgation of the soul, which leads to the reformation of the audience, lest they suffer a similar end.

The Character must be famous and prosperous or an illustrious man from a family of the kind. Aristotle's mention of Oedipus and Thyrestes as examples of who tragic heroes should be gives the idea that, in his view, tragic heroes should be of noble birth or should be of royalty as the names mentioned were royals and tragic heroes in Greek plays.

Gianni (2013) specifies that according to Aristotle, the tragic hero must portray some traits that cause the tragedy. They are Hubris (Pride), Harmatia (error or frailty) which is popularly known as tragic flaw, Peripeteia (Reversal) and Anagnorisis (Recognition). Whereas Hubris and Harmatia are personal traits exhibited by the tragic hero/heroine, Peripeteia and Anagnorisis are situations that the tragic hero faces in the plot which brings him/her to his/her fall and results in Catharsis.

Hubris is the pride that the hero shows against the natural order of life while Harmatia is the error, miscalculation or the frailty in the character of the hero/heroine which does not permit him/or her to attain his/her befitting end. In the plot, as the hero/heroine tries so hard to achieve a considerable height, the efforts work against him/her rather than propelling him/her. This is what is referred to as Peripeteia (Reversal). In the end; his/true hidden nature (self) becomes apparent to him/her. His/her flaw becomes evident but the whole situation at this point becomes irreversible. The long coiled string gets lose and uncoils by itself, leading to the unexpected end of the hero/heroine. This is what is called Anagnorisis (Recognition) as termed by Aristotle in his Poetics. Aristotle's main text for his analysis is Oedipus Rex by Sophocles

Aristotle argued that the development of the form of tragedy from the Dithyrambic chorus to its form as he described it was very slow. However, it got to a point as he described it and then the development stopped. He states:

Tragedy advanced by slow degrees; each new element that showed itself was in turn developed. Having passed through many changes, it found its natural form and there it stopped. (Butcher, 1902, p. 19)

By this, Aristotle perhaps meant that tragedy as he theorized it could see no further development. If it were so, then it was an unthinkable statement. This is because, once life still exists, there could be the possibility of development. Could tragedy remain stagnant in development as it was at the point he described it? Could there not be any new ways by which tragedy could be developed? Although, for many centuries, the Greeks, Romans, English, French and the western world carried out tragedy in the form as Aristotle theorized it, other concepts which would later give tragedy a new life and development from what Aristotle formed arose.

\subsection{Arthur Miller's Tragedy and the Common Man}

One person who stood vehemently against some of the things that the Aristotelian concept of tragedy presents, especially characteristics that qualify the tragic hero, was Arthur Miller, the American playwright, director and essayist. Arthur Miller in 1949 published his concept of tragedy which would later influence many playwrights of tragedy. This is what he called Tragedy and the Common Man.

Miller's concept was not an attempt to spit on Aristotle's theory of tragedy but rather to provide a window through which one could see the world from the perspective of the modern man. His concept 
does not therefore reject the entirety of the Aristotelian tragedy. What he focuses on is the social standing which is part of the traits that qualify the tragic hero.

As against Aristotle's claim that the tragic hero should be a prosperous and famous person, preferably person of royalty or nobility, Miller argues that the common man (the person who does not possess the prosperity and fame, royalty or of nobility as Aristotle claims is the ideal personality for the tragic hero/heroine) is also fit to be a candidate for tragic heroism. He thought this could resolve the challenge of lack of proliferation of tragedy as a result of the fact that the modern society lacks the prosperous and famous heroes; preferably kings, queens, princes, princesses and other royals that the Aristotelian tragedy endorses. This is because, the modern socio-economic and political era as has been fuelled by science has debunked the reserve of the tragic heroic right to the prosperous and famous (royals and of noble birth). Arthur Miller therefore believed that the tragic heroic reserve for the royals is outmoded.

Miller further explained that the common man is a complete candidate for tragic heroism in the sense that the Oedipus and Orestes complexes, modern psychiatry analysis theories, the formulations which were influenced by the tragedies of Oedipus and Orestes (royal beings) do not apply to people of royal birth alone but everyone in conditions similar to that of Oedipus and Orestes in that, not until tragedy as an art has been mentioned do people distinguish between the mental processes of the highly exalted and lowly.

Miller also argued that the purpose of the tragic hero is one; to regain one's rightful position in the society and it is characteristic of tragic heroes such as Orestes, Hamlet, Medea and Macbeth. In the attempt to seeking this rightful position, the fatal wound of indignity (the tragic flaw) empowered by indignation is revealed and leads to the unspeakable end of the hero. This indignation forces the hero to neither thread the course he has begun, without retreat nor surrender to the point where he fails. Once the hero/heroine begins the journey, there is no room for rescinding in his/her decision. Miller therefore defines tragedy as the "consequence of man's total compulsion to evaluate himself justly". He meant that tragedy happens when someone who is forced by his conscience to redeem his lost or defaced image fails. This he argued is not and cannot be the reserve of the highly placed personality in the society who had all the opportunities to live a better live. The tragedy of the common man who gives the whole of the little he has to reach out to his rightful place is therefore stronger than that of the kingly or nobility.

Miller in conclusion argues that the connotation of tragedy as a sad or unhappy end as has been in the definition of tragedy by many dictionaries is pessimistic and a misconception. He revealed that the struggle of someone to attain his rightful position in the society is an authentication of the genuine will of the human animal to realize his humanity. This must be optimistic rather than pessimistic. In this case of seeing tragedy as optimistic, pathos could therefore not be the end of tragedy. In its place "lies the belief-optimistic, if you will, the perfectibility of man." Plays such as The Crucibles, Death of a Salesman and many others by Miller explain his concept.

\subsection{The African Concept of Tragedy}

The introduction of literary drama into Africa came along with the introduction of the above discussed western theories of tragedy. However, Adade-Yeboah and Owusu (2013) argue that Africa has a tragedy concept that to some extent deviates from the western theories of the kind. A critical study of their concept for African tragedy reveals that, African tragedy does not in essence debunk the theory of tragedy by Aristotle. Neither does it embrace the focus of Miller's concept which is concerned with the social status of the tragic hero. Rather, it focuses on the force that propels the tragic hero into the tragedy and how the society embraces the tragic end of the hero and the consequence of the tragedy on the society.

According to Adade-Yeboah and Owusu (2013), basically, tragedy in the African sense is the consequence of the hero's resolute unconventionality. In African tragedy, the hero is always faced with dualistic patterns of life; his personal will and the social standards which are always in conflict. In this case, the hero, whether of nobility or commoner, fails in his mission as a result of his conservativeness to his more modifiable perspective of life rather than his liberality towards a strongly institutionalized system of the society. 
In African perspective, the tragic hero is identified by his uncompromising individualism and is therefore mostly ridiculed and laughed at by the society that always succeeds in the conflict, yet the individualistic stance of the hero is capable to cause a social change in the future. Adade-Yeboah \& Owusu (2013) use Things fall Apart, Morning Yet on Creation Day, Arrow of God all by Achebe and Ola Rotimi's Kurunmi as texts upon which their African concept of the tragedy and the tragic hero are based.

\subsection{Summary of the play Anowa by Ama Ata Aidoo}

The play Anowa as a tragedy tells the story of a young girl called Anowa: the daughter of Osam and Badua of Yebi, a land close to Oguaa at the coast of the then Gold Coast. It has been predetermined by the gods as has been revealed by many priests and priestesses that Anowa will become a priestess and not until she has become one will she know peace. However, against her father's delight to see her become one, Anowa develops an unflinching dislike to become a priestess.

Her mother gets so worried because Anowa neither does yield to her joy as a mother to see her daughter getting married to a prosperous man and giving birth to grandchildren for her. Anowa has rejected to marry any of the many men who pleased her parents as considerable suitors for their daughter. Anowa's stance against both the father and the mother are appalling to most people of Yebi, who think that a child like Anowa should be obedient to the parents and also have respect for the traditions of the people. Most people except Old Man curse her.

Anowa departs from Yebi with Kofi Ako, her lover and personal choice of man; against the will and blessings of her parents. Although her parents, especially the mother believes that Kofi Ako is lazy and cannot take good care of her daughter. However, Anowa's hope is to help her lover so that the two can change their fortunes in life. She leaves Yebi with her man to Oguaa under oath never to return again.

Years after, Kofi Ako against the control of Anowa becomes a slave dealer and becomes fabulously rich and highly elevated to a position of a sub-chief in Oguaa and becomes a council member of the chiefs of the coast. He dressed in Kingly regalia and was carried in palanquin as chiefs do. However, a queen though Anowa becomes, she does not dress any better and lives no better than she had left Yebi, years ago, because she abhors enjoying from the sweat of Kofi Ako's slaves.

Finally, Kofi Ako decides to divorce Anowa and take her back to Yebi without any explanation. But Anowa will not go until she finds out her husband's reason. Later, it comes to bare that Kofi Ako is impotent. Kofi Ako kills himself and Anowa drowns herself. Although, Old Woman, representing the people of Yebi and their traditional standards thinks Anowa deserves her tragic end, Old Man thinks that, Anowa's stance was a powerful one she dared to take and that she has set a new standard that posterity will uphold to effect social and cultural change.

\section{THE ANALYSIS}

\subsection{Anowa as a Model for the Aristotelian Tragic Heroine}

In proper consideration, Anowa as a tragic heroine fits for the Aristotelian tragic hero/heroine. This is because; she is neither an extremely virtuous person nor a bad person. She was a fairly good person. Whereas her decisions were quite good and worth dying for, they cut against the standards of tradition.

Again, Aristotle mentioned that the hero and heroine should be prosperous and famous; a noble person, preferably a royal. Although the play began with Anowa as a common person, she became a wife to the prosperous and famous Kofi Ako who rose to the status of a chief in the coast.

Whereas someone could become a royal by birth, another could become one by marriage, selection or by conquest. For example, although Oedipus, Aristotle's perfect example of a tragic hero was a true royal of Thebes, born to King Lius and Queen Jocasta, his ascension to the throne of Thebes was by selection and not by his royal birth. He was nowhere near the royal family at the time of his ascension to the throne of Thebes. He was selected to be the king by the elders of Thebes as an honour to him for rescuing Thebes from the payment of blood tribute to Sphinx as the Chorus sing in the opening of Oedipus Rex.

Again, Jocasta, Oedipus's mother and daughter of Menoeceus was not a royal until he had married Lius and later Oedipus (Wikipedia, 2016). In much the same way as Jocasta became a queen did 
Anowa become one. However, the difference is that, unlike in Jocasta's case where Lius was already a king; a royal or a noble person before he married Jocasta, Kofi Ako was not a prosperous and a noble person before Anowa married with him. Kofi Ako walked into the prosperity, fame and royalty together with Anowa.

Finally, Hubris and Harmatia are clearly identified in the character Anowa. Anowa's refusal to become a priestess and also to marry any of the men her parents selected for her are her hubris. Her decisions exhibit her proud nature against the social order of the people of Yebi (the gods who possessed her and the traditional standards of the people of Yebi).

On the other hand, her Harmatia or tragic flaw or error was her unbending posture regarding her decisions. Later in the plot of the play, her efforts to achieve a befitting end, thus by her singleness of purpose and unflinching nature to save her marriage did she fail, Having pushed Kofi Ako to at all cost reveal the reason he wanted to divorce her. That is the Peripeteia.

Finally, Anowa recognized that her oath never to go back to Yebi was a wrong decision. Kofi Ako had already shot himself to death and there was no way she could go back to Yebi because she was bound by the oath not to return to Yebi. She killed herself for that. That is the Anagnorisis.

From the above, it is explicit that Anowa fulfills the whole requirement of the Aristotelian tragic hero/heroine.

\subsection{Anowa as a Model for Arthur Miller's Tragedy and the Common Man}

In order to understand Anowa as fit to be a tragic heroine of the Tragedy and the Common Man concept of Arthur Miller, it is important to understand Anowa's philosophies of life. Anowa believes she was a common person and would want to live as such. She did not understand why some gods somewhere would want to possess her even against her will to live the life of a real human being. She must have seen this as an abuse of her rights. She took a firm decision to refuse to be a slave to the gods and was not bothered by the fact that it had been told that her failure to yield to the proposal of the gods would have a great evil consequence on her entire period of life. Later, the consequence of her resolute disobedience to the gods for the protection of her human right became a reality but she remained indifferent about it till death. Osam states:

But now there she is, as they said she might be, wandering ... her soul hovering on the outer fringes of life and always' searching for something ... and I do not know what! (Phase 2, p55)

The protection of human rights as Anowa's personal philosophy is revealed also in her struggle against her husband's interest in dealing in slaves. She felt it is inhumane for one to take another a slave for his personal gains. That is why she did remain uninterested even when her husband has become such a wealthy and powerful man in the land of Oguaa.

Anowa braced up herself to endure the proposed punishment for her disobedience to the gods. Kofi Ako's message from his friend (the seer) about Anowa's fruitless womb confirms the punishment of the gods to Anowa in her disobedience. Kofi Ako states:

But your soul is too restless. You always seem to be looking for things; and that prevents your blood from settling.(Phase 2, $p$ 50)

Again, set for marriage, Anowa questions the long existing tradition which gave the authority to her parents to select a spouse for her. She questioned why she is not allowed to make her own choice since it was to be her marriage and not the parents'. She states: "I do not care, Mother. Have I not told you that this is to be my marriage and not yours?"

In her attempt to free herself from the entanglement of the long existing society's influence on individuals with regard to entering into marriage, Anowa, against the will of her parents and the society's traditions chose her own husband and with him she swore to live until death parted them.

Also, Anowa questioned why society puts women below men by thinking that the woman must not think nor talk in order for her man to be a man. Old Woman states: "The dumbest man is always better than a woman." (Phase 2, p.64) In her attempt to defy this assertion of the society which is 
represented by Old Woman, she was herself and spoke her mind, took strong decisions she never rescinded, though she knew the results of her decisions could be perilous. One of such decisions was her refusal to enjoy in Kofi Ako's dirty wealth, undeserving fame and authority.

Another thing Anowa fought against in the society as a common person was the injustice against women by some men who divorce their wives without offering any tangible reasons. Anowa would not leave Kofi Ako until she came viz-a-viz with the whole reason the man she had sacrificed her family for wanted to divorce her. To Anowa, all the things she fought against were dehumanizing and humiliating to her life and needed to be questioned. This decision to know the reason Kofi Ako wanted to divorce her at all cost later led to her death.

In the end, it is obvious that the points raised above prove beyond reasonable doubt that Anowa's death by drowning herself is the consequence of her attempt to evaluate herself justly. We see a solitary common person; a person without any fame and prosperity fighting all alone against the long existing natural or social order of her part of the world in her attempt to live her life as she understood life to be, preferring the death of a pauper to living a pleasurable life from the sweat of bond men and dared not to return to Yebi. In the end Old Man states: "She is true to herself. She refused to come back here to Yebi, to our gossiping and our judgments." (Phase 3, p.89) This makes Anowa a true model for the Tragedy and the Common Man by Arthur Miller because she gave all she had to keep her integrity and philosophies of life as a person.

\subsection{Anowa as a Model for the African Concept of Tragedy}

Anowa as a tragic heroine also provides explicit exhibition of African tragic heroine. Alone, she fought against the long existing suffocating social standard which failed to recognize that who feels it knows it best and gave parents the absolute authority to dump a man of their choice on the daughter. Her resoluteness to select her own spouse and her oath never to return to her parents, maybe to excuse herself from complaining to them about the behaviour of the man she selected for herself from among many others, and her eagerness to stay with him and turn the so known worthless young man into a useful somebody. However, this was but an individualistic undertaking Anowa engaged in against the ethos of a whole society. By this, the society considered her a recalcitrant, outlaw and troublesome because she judged the standards of her people with impudence. Old Woman, representing the society states:

She thinks our forefathers should have waited for her to be born so she could have upbraided them for their misdeeds and shown them what actions of men are virtuous. (Phase 2, p.63)

Again, whereas the society did not care much about how people gain their wealth, Anowa argued that some ways of wealth creation are evil and must not be condoned. Whereas her society saw nothing wrong with dealing in slaves and living glamorously by their sweat, she saw it contrarily. Kofi Ako states: "What is wrong with buying one or two people to help us? They are cheap. Everyone does it...does not everyone do it?" (Phase 2, p.52)

However, Anowa sees this cherished practice of the society as no different from the white dominion of over the Africa she lived in at the time the play was set ( around early1900s) and would always argue against the inhumane act of people enslaving others. This motivated her to live in the wretchedness she had left Yebi with even when Kofi Ako was overflowing in wealth because she did not want to enjoy from the sweat of her husband's slaves.

In the end, even after Anowa's death, Old Woman; who represents the masses subjective nature blames Anowa for the death of Kofi Ako. Old woman states: "Was it not that Anowa who made him shoot himself? "(Phase 3.p89) That was the way her people of Yebi reacted to her tragic end. That is to say the pathos that Anowa deserved was from the people of Yebi are lacked. In its place is the ridicule of the society for her failure in her supposed defiance against the traditions of Yebi. Old Man who represents social change bursts out:

It is men who make men mad. Who knows if Anowa would have been a better woman, a better person if we had not been what we are?....She is true to herself. She refused to come back here to Yebi, to our gossiping and our judgments. (Phase 3.p89)

Although, most parents of Yebi might have used Anowa's failure as a reference point when trying to hold on to the firm authority society had given them to choose spouses for their children, other girls 
who thought like Anowa concerning the selection of a spouse would have the courage to make their own decisions because Anowa had set the pace for them.

By the analysis above, it will not be wrong for one to argue that the play Anowa fits as a perfect model for the tragic heroine in the African context of tragedy.

\section{CONCLUSiON}

A critical analysis of the tragic heroine Anowa in the tragedy Anowa reveals that Aidoo's Anowa has got no match when it comes to the question of the best ever tragedy and tragic hero/heroine. Not even Sophocles' classic Greek tragedy; Oedipus Rex which Aristotle used to underpin his theory of tragedy nor any other from Sophocles, Aeschylus, Euripides, William Shakespeare, Arthur Miller nor any other known tragedy can compare with Anowa; for Anowa is an embodiment of all the three theories of tragedy as have been discussed in this paper and the tragic hero/heroine and therefore serves three purposes in one tragic drama.

Anowa provides a unique approach to the theory of tragedy by Aidoo. This is what we call Topnotch Tragedy. Topnotch here may be considered as attaining the outmost standards of excellence or quality. The Topnotch Tragedy therefore should have the most complex plot and a multi-tragic concept hero/heroine.

Topnotch tragedy is the tragedy that allows a two or more tragedy concepts to live harmoniously yet individually. It therefore recognizes the tragic hero/heroine as someone who moves from one social class to another; say from nobility to a commoner or vice-versa but maintains both contradictory statuses, in pursuit of his dreams but falls flat due to his/her weakness that he/she is unable to overcome, leading some audience into pity and fear but others into laughter and ridicule for their triumph but the failure at the same time leaves an opened door for social change. This is the unique African approach to tragedy as has been set by Ama Ata Aidoo through her Anowa.

A hero or a heroine in topnotch tragedy concept must like Anowa:

- Move from his or her original social class to another but lives with the two at the same time. For instance, Anowa was a common person but became a queen. However, he lived the two antithetical social statuses till her tragic end in her attempt to "evaluate herself justly".

- Pursue a dream as an individual. In the case of Anowa, she pursued her philosophy of protection of human right as a solitary figure as opposed by the whole society.

- Be seen as an outlaw by society. Anowa was seen as an outlaw to the society

- Fail by a flaw. Anowa's flaw was her edge to have her will do at all cost.

- Induce pity and fear in others by his/her failure in mission.

- Cause others to rejoice by his/her failure

- Leaves an opened door for social change by his stance.

\section{RECOMMENDATION}

Realizing how beautifully Aidoo's Anowa has set a new concept for tragedy, it is recommended that playwrights should begin to adopt this method of Ama Ata Aidoo to create new tragedies with most complex plot structures that are embodiment of different concepts of tragedy. This will serve audience with interests in different concepts of tragedy at the same time with one play for convenience and suitability.

\section{REFERENCES}

[1] Adade-Yeboah, A.\& Owusu, E. (2013). Tragic hero of the modern period: the African concept. English Language and Literature Studies, 3(4) Canadian Center of Science and Education. Retrieved on 20th July, 2016 from www.ccsenet.org/journal/index.php/ells/article/viewFile/32258/18932

[2] Aidoo, A. A. (1969). Anowa. (Pupils' Ed. 2003). Edinburg: Pearson Educational Limited. Aristotle, Poetics. Trans. Butcher, S.H. (1902). The Poetics of Aristotle. (Third Ed. Revised). Macmillan and Co. Limited, London.

[3] Cartwright, J. (2013). Greek tragedy. Ancient History Encyclopedia. Retrieved 22nd July, 2016 from www.ancient.eu/Greek_Tragedy 
[4] Gianni, D. (2013). Theatre of the ancient Greece I: background, plays and playwrights. Retrieved 24th July, 2016 from heironimohrkach.blogspot.com/2013/06/the-theatre-of-ancient-greece-i.html?=1

[5] Grainger, R. (2014). Theatre and encounter: the psychology of dramatic relationship. Retrieved 20th July, 2016 from Amazon.com

[6] Hamilton, C. (2012). The theory of theatre and other principles of drama. HumanitiesWeb.Org. Retrieved 22nd July, 2016 from www.humanitiesweb.org/spa/ID/1436/o/blank

[7] Miller, A. (1949). Tragedy and the common man. The New York Times on Web. Retrieved 22nd July, 2016 from www.nytimes.com/books/00/11/12/specials/miller-common.html

[8] Prince, N., \& Jackson J. (1997). Exploring theatre. McGraw-Hill. Texas

[9] Sewall, R. B. (2016). Classical tragedy. Retrieved 14th July, 2016 from global.britannica.com/art/tragedyliterature

[10] Sifakis, G.M. (2003). Greek tragedy. Macmillan Encyclopedia of Death and Dying. Retrieved 22nd July, 2016 from www.encyclopedia.com/doc/1G2-34072001.htm

[11] Stanudd, S. (2006). Aristotle's poetics. Retrieved on $27^{\text {th }}$ June, 2016 from www.stenudd.com/aristotle/ aristotle-poetics.htm

[12] Wikipedia (2016). Jocasta. Retrieved $24^{\text {th }}$ July, 2016 from http://en.wikipedia.org/wiki/Jocasta

[13] Worthern, W.B. (2004). The Wadsworth Anthology of Drama. (Fourth Ed.).Cengage Learning EMEA. London.

Citation: Samuel Yirenkyi Stephen Yaw Oppong. "Redirecting Tragedy towards the Unique Approach of Ama Ata Aidoo's Anowa". International Journal on Studies in English Language and Literature (IJSELL), vol 6, no. 1, 2018, pp. 43-51 doi:http://dx.doi.org/10.20431/2347-3134.0601007.

Copyright: (C) 2018 Authors. This is an open-access article distributed under the terms of the Creative Commons Attribution License, which permits unrestricted use, distribution, and reproduction in any medium, provided the original author and source are credited. 